$1963-2$

\title{
A Proposal to Reduce Misallocation of Livestock Grazing Permits
}

B. Gardner Delworth

Brigham Young University

Follow this and additional works at: https://scholarsarchive.byu.edu/facpub

Part of the Agricultural and Resource Economics Commons

\section{BYU ScholarsArchive Citation}

Delworth, B. Gardner, "A Proposal to Reduce Misallocation of Livestock Grazing Permits" (1963). Faculty Publications. 3104.

https://scholarsarchive.byu.edu/facpub/3104

This Peer-Reviewed Article is brought to you for free and open access by BYU ScholarsArchive. It has been accepted for inclusion in Faculty Publications by an authorized administrator of BYU ScholarsArchive. For more information, please contact ellen_amatangelo@byu.edu. 


\section{A PROPOSAL TO REDUCE MISALLOCATION OF LIVESTOCK GRAZING PERMITS*}

\section{B. Dellworth Gardner Utah State University}

T THE federal government owns about 400 million acres of land in the eleven western states. Almost 350 million acres are administered by the Forest Service and Bureau of Land Management. In times past most of this land has been used for grazing by domestic livestock. Only approximately 60 million acres of forest range are presently grazed by livestock, while about 160 million acres of "district" land, administered by the BLM, are grazed.

The first section of this paper is a description and critique of current practices used by these agencies to allocate grazing services. The following sections present a proposal to effect changes in allocating and pricing public grazing that would improve economic efficiency, both in getting the permits to livestock operators who value them most highly and in securing more investment in range improvement and in range care and management.

\section{Rules for Issuance of Grazing Permits}

The Forest Service and the Bureau of Land Management administer livestock grazing as part of multiple-use programs. Although some minor differences exist, the essential components of their grazing administration procedures are quite similar. Let's briefly look at each system, starting with that of the Forest Service.

Within each ranger district of a national forest, the ranges prescribed for livestock grazing are separated into range allotments in order to facilitate grazing administration.

The allotments are established so as to conform to natural grazing units insofar as topography, water, adaptability of forage for different classes of livestock, present ownership of improvements and ranch property, and the demand for forest range will permit. The allotment, insofar as possible, should conform to district boundaries. ${ }^{1}$

If an allotment is small enough, it may be allocated to a single permittee; but often allotments are so large they require "community" use by several permittees.

* This paper was written while I was a Ford Foundation Faculty Research fellow. I extend thanks to the Foundation for financial support. The Foundation bears no responsibility for the views expressed herein, however; they are entirely my own. Colleagues N. K. Roberts, E. B. Wennergren and Lois Cox have read an earlier manuscript and have made valuable suggestions for its improvement.

${ }^{1}$ Forest Service Manual, Title 8, Range Management, Washington, U.S. Government Printing Office, p. 12. 
In most cases the rancher must qualify for "preference," after which he might obtain a permit to graze an allotment. The permit authorizes the grazing of livestock under specific conditions and expires on a certain date. Current forest permits will all expire in 1965 and must be renewed at that time. When renewed, permits generally provide for ten years of grazing.

Preference is not synonymous with a permit, however, since a preference is continued until canceled or revoked. ${ }^{2}$

Preference may be acquired by:

1) Prior use of certain lands before inclusion of such lands in a National Forest. After creation of a forest, only those individuals who submit proof that they used the forest range two consecutive years immediately preceding the year in which the new forest was established, can be assigned a preference. In no case can the number of stock in the permit be increased from the average number grazed on the range prior to its becoming a forest.

2) Renewal of a permit formerly held by a co-partnership or corporation to each individual member for a number of livestock equal to his share in the original permit, or by pooling of preferences.

3) Purchase of a permittee's livestock or ranch, or both under circumstances justifying a renewal of preference.

4) Inheritance of a permittee's livestock or ranch, or both under circumstances justifying a renewal of preference.

5) Regular use of forest range under temporary permit for five consecutive years, and ownership of commensurate ranch property.

6) Restoration of preferences reduced for range protection.

7) Increase in existing preference on account of increased grazing capacity resulting from development work by the permittee. ${ }^{3}$

Even though an applicant for a permit obtains preference in one of the ways enumerated in the foregoing list, this is not sufficient for issuance of a permit. A rancher must also meet the ownership, dependency and commensurability prerequisites below:

1) Ownership. Both the livestock that graze forest range and the commensurate ranch property must be owned by the permit applicant.

2) Dependency. Property is recognized as dependent when there is need for the forest range to round out a year-round operation and to obtain proper and practicable use of commensurate property. If a ranch contains all the range and hay land that are required to support the livestock, then no need for forest range exists and the land cannot be said to be dependent.

3) Commensurability. Property will qualify as commensurate only when it is a recognized livestock operating base and is complementary to national forest range in rounding out a properly balanced year-long

${ }^{2}$ Ibid., p. 97. 
livestock operation. Generally, this requirement necessitates that the base ranch must have sufficient land, water, housing, etc., to support the livestock through the period of time when they are off the forest.

In addition to the foregoing requirement, unused grazing quantities also must be available on the allotment in question before permits are made available. That is, Forest Service officials must sanction the creation of a new preference or the transfer of an old one and the issuance of a new permit. Over the past thirty years, livestock grazing has been almost continuously reduced and new permit creation has been severely restricted.

Once a permit is granted to a particular rancher, transfer to another rancher may be difficult and costly. Two other factors besides the imposing regulations cited above tend to impede transfer.

Until 1954 the policy of the Forest Service was to cut grazing when permits were transferred. Stockmen are not convinced that this policy has been abandoned entirely. Cuts have continued over the years, but have not coincided with transfers. If ranchers fear a transfer will eventually produce a cut, then an obvious impediment to transfer exists.

The second factor that may impede transfer is existence of an "upper limit" in terms of grazing numbers that any permittee may graze. The alleged reason for limits is to prevent the large rancher from acquiring the bulk of the public grazing. The maximum number of livestock permitted to a single stockman varies with each forest and in some cases is as low as 150 cattle or 3600 sheep. No doubt this policy results in wider permit distribution among ranchers, but it also restricts transfer to the larger ranchers if they are operating at or near the limit.

The Bureau of Land Management leases grazing quantities under two types of preference, the "permit" and the "temporary license." The permit is the preferred and most common type. As with forest permits, local, bona fide stockmen are given priority.

Preference in the granting of grazing privileges will be given to those applicants within or near a district who are landowners engaged in a livestock business, bona fide occupants or settlers, or owners of water or water rights, as may be necessary to permit the proper use of lands, water or water rights owned, occupied, or leased by them. ${ }^{4}$

The prerequisites for obtaining a permit resemble those of the Forest Service. The terminology in the regulations is different. Applicants must own or control land or water in Class 1 . Class 1 land is land dependent by use as defined below. Class 1 water is full-time prior water also defined below. Both "priority" and "commensurability" are evident in the following definitions:

${ }^{4}$ U.S. Department of Interior, The Federal Range Code, Washington, U.S. Government Printing Office, 1956, p. 1. 
'Land dependent' by use means forage land and water other than federal range of such character that the conduct of an economic livestock operation requires the use of the federal range in connection with it and which, in the 'priority period,' (five years before range was included in grazing district) was used as a part of an established, permanent, and continuing livestock operation for any two consecutive years or for any three years of such priority period in connection with substantially the same part of the public domain, now part of the federal range.

'Full-time water' means water which is suitable for consumption by livestock and available, accessible, and adequate for a certain number of livestock during those months in the year for which the range is classified as suitable for use. 'Prior water' is water which during all or not less than two years of the priority period was used to service certain public domain now part of the federal range for a livestock operation that was established permanent and continuing, and which normally involved the grazing of livestock on the same areas of public land for a certain portion or portions of the year of such use. ${ }^{5}$

Next in order of preference are applicants who own or control land or water in Class 2. Class 2 land is land dependent by location.

Land dependent by location means forage land other than federal range, which is so situated and of such character that it can properly be used as base for an economic livestock operation utilizing the forage resources of the federal range. ${ }^{6}$

"Federal range" is a term used in the Code in referring to lands in the established grazing districts administered by the Bureau of Land Management.

Class 2 water is "full-time" water, which has already been defined.

Applicants in either of these preferred categories may be issued permits which generally have a ten-year duration.

Although forest and BLM allocating systems are similar, some differences are worth noting.

In the BLM system, leased private, state, or even other federal lands (as long as they are not public domain lands) may be used as part of the "dependent" base property. This policy greatly weakens "commensurability" as an effective prerequisite. The BLM rules place even greater emphasis upon "priority," however, than do the forest rules. In fact, the preferred group has land and/or water in Class 1 that is (are) "dependent" by prior use and location. Class 2 lands and water are "dependent" by location only. The heavy emphasis on priority of use ties the public range to a given base ranch even more closely than does emphasis on commensurability. Many ranchers in an area may qualify on a commensurate basis, but only a few may be prior users.

\footnotetext{
'Ibid., pp. 2-4.

Ibid., p. 3.
} 
Forest permits may be transferred with the sale of livestock. The BLM rules do not contain this provision. The BLM regulations contain no upper limits on grazing numbers of livestock as do forest rules.

Despite these technical differences, the effects of the rules of these two agencies have been the same. Grazing permits in both instances are closely tied to certain ranchers and/or ranches, and transfers are difficult simply because other ranchers or base properties may not meet the preference prerequisites.

The relative infrequency of forest permit transfers is indicated by the following data. ${ }^{7}$ From 1948 to 1952 the average number of permits transferred annually was 5 percent of the total. If it can be assumed that this is a typical period, one turnover for each existing permit would occur every twenty years. Since permits are issued to individuals and transfer is required in normal inheritance proceedings, a 2-4 percent annual turnover could be expected from this source alone. Further, each time a ranch with a permit is sold, a transfer to the new owner is required. These facts suggest that only rarely was a forest permit actually transferred from one ranching setup to another.

I have argued elsewhere ${ }^{8}$ that the nonprice allocating schemes of these agencies could be causing misallocation of public grazing; i.e., the permits are being rationed to some users who would not obtain them if they were allocated by a free market.

Essentially, my argument is that the transfer restrictions prevent the movement of the grazing services to ranches and ranchers where they would have maximum value. The evidence indicating misallocation is substantially the following:

1) Historically, the BLM and forest fees often have been below the value of the marginal product of public grazing.

2) If transfer of permits were unrestricted, the differential between the fee and the value of the marginal product of grazing would get capitalized into permit values, assuming perfect competition in the market for permits, certainty of grazing tenure, and no capital rationing.

3) In fact, however, the actual permit values are less than the capitalized differential; it seems unlikely that uncertain grazing tenure, market imperfections, or capital rationing can explain the disparity.

The conclusion is that transfer restrictions (the nonprice rules and prerequisites for obtaining permits) could be preventing public grazing from moving to ranchers who would acquire these services if the permits were freely transferable and market-allocated.

\footnotetext{
"Report of Chief of Forest Service, 1953, "Grazing on the National Forest," Washington, U.S. Government Printing Office, p. 12.

${ }^{8}$ B. Delworth Gardner, "Transfer Restrictions and Misallocation in Grazing Public Range," J. Farm Econ., Vol. 44, 1962, pp. 50-64.
} 
An alternative frequently suggested to "solve" the efficiency problem postulated in the foregoing section is to allow the grazing lands to pass into private ownership. This "solution" has many facets and ramifications, only a few of which will be discussed here.

It is quite possible that private ownership of all grazing lands could solve some aspects of the grazing efficiency problem. Conceivably, the grazing would pass into "efficient" hands in the sense that all other market-allocated services do, and investment in range improvement might also be optimized in the sense that owners will undertake "profitable" improvements. The fact that all public grazing lands are multiple-use lands, however, causes the situation to be somewhat more complicated, and creates doubts as to the efficacy of the rancher ownership solution.

Simply because the public grazing lands are multiple-use lands, the problem does not differ in kind from an efficiency problem where only one use is involved. That is to say, if the owner of the lands could sell the multiple-use services, without restriction, to the beneficiaries of those services, then an efficient solution might very well obtain. The problem isn't as much conceptual as technical.

Due to the nature of the services and the problems of collecting rentals from the beneficiaries in the present legal and institutional setting, an efficient solution would be difficult and probably impossible. To cite just one example as being illustrative, nearly all western forest and district grazing lands are grazed by game. If all ranges were privately owned by stockmen, they could try to fence out game or, alternatively, sell hunting services. Both are difficult to conceive as practicable. Fencing costs to contain game would likely be prohibitive; therefore, other measures of control would be necessary. If the rancher attempted to sell hunting services, it is very difficult to see how he could collect. The space is too vast; the hunters too numerous. Any kind of effective hunting program would complicate his ranching business, to say the least.

Likewise, it is difficult to see how ranchers could collect for watershed or flood control benefits. I don't mean to imply that these problems are nonexistent under public ownership. Problems of identifying beneficiaries and collecting for benefits exist regardless of who owns the land. However, the efficiency problems might very well be more serious under private than under public ownership. Public officials might well make better judgments about overall resource use than private owners who are specialists in one or a few uses only. In any case, I assume that the government agencies will continue to administer the multiple-use lands and that they will determine, according to their best lights, the quantity of livestock grazing to be allowed. Our problem then becomes-how can this grazing be allocated most efficiently among ranchers? 


\section{The Proposed Nature of the Allotment and Permit}

Two goals are paramount in determining allotments in the forests and grazing districts: 1) allotments should meet certain physical conditions to promote efficient grazing control and administration; and 2) allotments should have appropriate character and size to permit exclusive use by a single permittee, insofar as practicable.

The location and size of each allotment will be influenced by innumerable factors. Grazing has been discontinued on many acres of public land for various reasons. Some ranges have been overgrazed, and grazing on these has been terminated pending range recuperation. Certain kinds of terrain are inaccessible or dangerous for livestock. Other areas may be devoted exclusively to uses such as recreation or watershed protection. The movement of livestock is generally controlled on allotments by fences or natural barriers. From the administration point of view the size of the allotment must be influenced by the natural topography of the area, the cost of fencing, accessibility to the grazing area, control of trespass, and water conditions. No doubt, the agency officials are in the best position to determine the boundaries and nature of the allotment. The primary criterion logically would seem to be to minimize the cost of establishing and maintaining the allotment per grazing unit, while giving consideration to the exclusive user principle.

Exclusive use is important to range management and investment considerations. The practice of having several permittees graze a "community" allotment is not conducive to individual range care or investment in range improvement. Although notable examples could be given of permittee cooperation in project development, many more cases exist where collective action of this kind is conspicuously absent. Why should one rancher protect or improve the range when many of the benefits will accrue to others? Whenever investment is attempted collectively, there are problems of equitable assignments of costs and returns. Furthermore, the government agency must always be a party to such agreements, particularly in the decision as to who gets the benefits. Far fewer problems would arise if each permittee had his own allotment and was completely responsible for it.

Of course, exclusive permittee allotments may not be feasible in all situations because costs involved in fencing, etc., would offset the advantages. It is possible, however, that more individual allotments could be provided than at present.

Security of grazing tenure would be increased if the permit were a "right" to graze a given number of AUM's (animal-unit-months) in perpetuity. This would be a rather radical shift from present philosophy. The government agencies have always maintained that grazing is a privilege, not a right. ${ }^{9}$ This policy has made it easier for the agencies to alter

\footnotetext{
${ }^{\bullet}$ Forest Service Manual, op. cit., p. 93.
} 
the quantity of grazing whenever range conditions required it, but this same end could be achieved in another, more equitable way. In fact, forest grazing has been cut in half since 1933. The cuts have produced two undesirable phenomena that guaranteed grazing in perpetuity would overcome.

As permits have been cut, and because livestock people expect the trend to continue, security of grazing tenure has been reduced. Investment in range improvement that would have been undertaken under more optimistic tenure expectations has been curtailed. On the forests, where heavy grazing cuts have been made, rancher investment has declined sharply. The rancher investment in forest range improvement in 1957 was only 6 percent of the rancher share in $1949 .{ }^{10}$ Over the identical time period, rancher investment on the BLM districts, where little or no cutting has occurred, increased by 327 percent. ${ }^{11}$ There can be little question that "perpetual" grazing would tend to augment rancher range management and investment.

Secondly, I have already pointed out that public grazing has been underpriced; i.e., the fee has been set below the value of the marginal product. As a result, grazing permits have considerable value. I found in 1958 that forest permits had an average value of $\$ 16.45$ per AUM of grazing in northwestern Colorado, while district permits were worth $\$ 10.92$ on the average. ${ }^{12}$ When permitted grazing is reduced by the agencies, ranchers suffer a substantial wealth loss. Perpetual grazing rights would eliminate cuts and rancher wealth losses.

One objection to the perpetual rights proposal is that agency power to set the quantity of grazing is weakened. This may be unwise in light of multiple-use management considerations and the vagaries of weather that greatly affect range condition. In my judgment, the government agencies should maintain control over the quantity of grazing, perhaps even on a year-by-year basis. Multiple-use goals should be pursued as under the present setup.

Agency control of grazing quantities isn't necessarily incompatible with the perpetual rights idea if a stipulation is attached. The "security" and "wealth loss" criticisms of present practices can both be surmounted by a simple policy provision. As already suggested, the government could issue perpetual rights to graze a certain amount, while retaining the prerogative to alter the grazing quantities allowed. If the right were cut, however, the government would be required to compensate the permittee for his loss. The extent of the compensation would be the market value

\footnotetext{
${ }^{10}$ Data taken from Report of the Chief of Forest Service, 1953, USDA, Washington, U.S. Government Printing Office, 1953, p. 9, with supplemental data from private correspondence with Forest Service personnel.

${ }^{11}$ M. Clawson and B. Held, The Federal Lands, Baltimore, Johns Hopkins Press, 1957, Appendix Table 33, p. 444.

${ }_{12}$ "Transfer Restrictions ...," op. cit., p. 59.
} 
of the AUM's of grazing that are eliminated. If rights are freely bought and sold, as I suggest later, the market value would be readily determinable. Surely, if the rancher is assured of compensation for grazing cuts, insecurity would not impede investment nor would he suffer wealth losses. The law already specifies that permittees will be compensated for the loss of capital assets on public lands in case of grazing reductions. It would be a simple extension of the law to compensate for grazing cuts also. If the government agencies were required to compensate permittees for losses, they probably would be quite careful about making unnecessary or discriminatory cuts. On the other hand, the proposed compensation policy might hinder proper regulation of grazing intensity. The agencies would have to be given the funds to permit them to make needed grazing adjustments for resource protection.

In summary, the proposed permit would guarantee a given amount of grazing in perpetuity on a given allotment unless the government wished to reduce the grazing quantity, in which case the permittee would be fully compensated.

\section{The Allocating and Pricing of the Permit}

The overriding consideration in any resource policy should be efficiency in terms of maximizing the product to be taken from the resources over some relevant time horizon or, alternatively, minimizing the cost of taking a given quantity of product. Of course, if resources have multiple uses, it is the value of the multiple products that should be maximized. Equity considerations may also be important, especially if a vastly different resource and income distribution results from alternative policy proposals. In the case of public grazing, if permittees are compensated for wealth losses resulting from grazing cuts, equity problems are minimized.

Present prerequisites for holding permits such as "priority," "commensurability" and "ownership" hinder efficiency. They probably originated as a mechanism to assure local, prior users that their use of the range was not in jeopardy when government control was instigated. In a sense, they have accomplished this objective-permits have been tied to certain ranches or ranchers. Simultaneously, transfer has been made difficult. It is time now to eliminate these prerequisites and let the permits move to ranchers who value them most.

There are many ways this can be accomplished. The alternative that I prefer is for the government to create perpetual permits covering redesignated allotments as described above, and to issue them to ranchers who presently hold permits in exchange for those now in use. These permits would be similar to any other piece of property that can be bought and sold in a free market. These permittees would be completely free to retain or to dispose of the new permits to whomever they wished, for whatever price they could agree on. Permits would be passed on to heirs 
as can any other private property. Some restrictions may be necessary to maintain efficient, exclusive allotments. Flexibility would be increased if the permit were divisible and could therefore be sold or inherited in smaller portions if desirable. Perhaps, some lower limit would have to be imposed to prevent allotments from being subdivided into units too small to be efficiently administered by the government agencies. Divisibility might improve allocative efficiency but would likely produce a "community" pattern of use with attendant problems of inaction with respect to range improvement and management. Final determinations of questions like this one must be postponed pending experience with the new program and some empirical estimates of relevant parameters. In any case, the government agencies would have to be kept informed about the identity of the permittee (permittees) if transfer occurred, so they could check grazing practices, especially trespass, and collect the grazing fee.

As indicated earlier, it may be necessary to change the quantity allocated to grazing from time to time. If additional AUM's of grazing become available on an allotment because of permittee investment or management, the permittee would be allowed to harvest the grazing for the set fee. If more allotments are created on land previously ungrazed, or result from agency investment, the new permits could be sold at auction. Close cooperation between permittees and the agencies would be required to make these kinds of appraisals. If grazing were diminished, the government would simply buy up permits in the market. ${ }^{13}$

The annual fee per AUM collected by the government could be set at any level below the value of the marginal product of the grazing. If set at the value of marginal product, the permit would have zero value and could not be bought and sold. Risk to the stockman would be minimal if the fee were fixed: that is to say, if it were constant over time, or perhaps fluctuated with general price level movements. This would enable each rancher to ascertain how much he could afford to pay for the permit in addition to the fee. The simplest fee level to administer would be zero; however, Congress may insist that the fee be set at a level that would at least cover costs of grazing administration, a procedure that has been used in the past by the Bureau of Land Management. Fees based on administrative costs are not satisfactory, however, since this practice may generate pressures to reduce administration below the levels necessary for effective management.

If the fee were set at a level near the present fee for both forest and district permits, it seems certain that windfall gains would be created

\footnotetext{
${ }^{13}$ Of course, the situation may be quite complex in some cases. Agency officials may wish to have grazing reduced or eliminated on specific allotments where the permittee is unwilling to sell. In case of impasse in negotiations between the agency and the permittee, I would suggest some provision that would require an appraisal of value of the diminished grazing by some independent party. This policy seems preferable to public condemnation where agency discrimination against the stockman might more readily occur.
} 
for present permit holders, assuming that the new perpetual permits were issued in exchange for the "old" ones. The fact that grazing would be guaranteed in perpetuity or compensation paid if grazing is reduced would almost certainly increase permit values. Furthermore, permit values would increase if all prerequisites for holding them were abrogated.

If the fee were set at the value of marginal product, the permits would have no value; if set at present fee levels, the new permits would have greater value than the old ones presently do. It follows that at some fee level above current levels the new permits would be worth, on the average, exactly what the old ones are now. To avoid windfall gains as much as possible, the government might try to ascertain what this fee level would be and charge it. Since some allotments are worth more per AUM than others, charging a single fee over the whole region would make it impossible to completely eliminate windfalls and losses in the exchange process. The fee could be chosen, however, so that, on the whole, windfalls accruing to some permittees would just offset losses taken by others.

\section{The Impacts of the Proposal}

It has already been suggested that adoption of this proposal would stimulate range management and rancher investment in range improvement. If ranchers have exclusive allotments and security of grazing tenure, they could reasonably be expected to make better decisions with respect to range care and improvement. I have shown in another study ${ }^{14}$ that net returns to range improvements are considerable on Colorado ranches and that "underinvestment" in improvement practices probably is rather general. Perhaps even more important, eliminating permit transfer restrictions would improve allocative efficiency by allowing permits to move to the most efficient ranchers. Furthermore, all other uses of the public lands that depend on forage production would also be increased in value if the proposal were implemented. These gains would seem to be substantial.

A question might be raised about the distribution of the permits under the proposed system. If these permits are likely to pass to large operators, rancher incomes might become more disparate than under the present systems, which undoubtedly discriminate against the large operator. To the extent that the larger ranchers have more efficient operations and can afford to pay more for the permits, the proposed system would reinforce this likelihood. On the other hand, large ranchers might be expected to have better-balanced operations without the public grazing, whereas small ranchers with irrigated cropland might have need of additional

${ }^{14}$ B. Delworth Gardner, "Rates of Returns to Improvement Practices on Private and Public Ranges," Land Economics, February 1952, pp. 43-50. Also B. Delworth Gardner, "Costs and Returns From Sagebrush Range Improvement in Colorado," Agric. Experiment Station Bulletin 511-S, Fort Collins, Colorado, 1961. 
seasonal grazing; in which case, they will value permits most highly.

Even if the permits did pass to fewer and larger operators, it is difficult to argue that this would be undesirable. If small operators who hold permits currently and are therefore issued the new type choose to sell rather than hold them, it can't be argued they are worse off as a result. By permitting free transfer of the new permits and compensation for grazing reductions, the distribution problem evaporates.

If many small operators should decide to discontinue ranching because they choose to sell their public grazing, then local, rural communities may suffer somewhat through these "neighborhood" effects. This phenomenon is rapidly occurring anyway because of other factors such as technological development and economies of scale. The total gains to the economy in the long run, however, would almost certainly more than offset these local losses after all relevant factors make "efficient" adjustments.

There may be some initial governmental costs in implementing and administering the proposal. Exclusive allotments may require more fences. The exchange of new permits for old will require some extra work, but this task should not be so burdensome as to be beyond the capabilities of present personnel and resources of the agencies. The heaviest potential cost to government probably would be in compensating ranchers for grazing losses if the government buys up some permits. These costs, however, could be offset by the imposition of higher fees. Also, the increased productivity of the range eventually could result in more public grazing. My own opinion is that these two possibilities for returns might more than offset any costs of compensation over the long pull.

It must be obvious that I have included only a skeleton of the proposal. Many details have not been specified, pending debate and subsequent acceptance or rejection of the essential components of the program. The primary purpose of this paper is to offer the proposal for public discussion. ${ }^{15}$

Others in the profession undoubtedly have alternative schemes. This is one that I believe has great promise in terms of solving the problems at hand with only "minor" difficulties involved in implementation. Perhaps ultimately, out of debate and discussion, a grazing policy will emerge that will increase the productivity of the vast public lands in the west.

${ }^{15}$ After I had submitted this article to the Journal, my attention was called to an article, "Economic Analysis of Land Use on the Western Ranges," by M. M. Kelso that appears in The Annals of the American Academy of Political and Social Science, Vol. 281, May 1952, pp. 135-145. Kelso reaches conclusions and makes recommendations quite similar to my own. I lay more stress on the perpetual nature of the right than does he. Also, the compensation provision is unique in my proposal. We would set the fees at different levels-he at the competitive value of grazing and I below that level so as to maintain stockman equity in the permit. My proposal is also more complete in many details that Kelso did not choose to discuss because he was covering a much broader topic. However, I think it most interesting that our "solutions" are so similar considering their independent origins; certainly, I am complimented that Kelso's conclusions substantiate my own. 